\title{
Determining the duration of Aphis glycines (Hemiptera: Aphididae) induced susceptibility effect in soybean
}

\author{
Adam J. Varenhorst ${ }^{1} \cdot$ Michael T. McCarville ${ }^{1} \cdot$ Matthew E. O’Neal $^{1}$
}

Received: 8 April 2015/Accepted: 19 August 2015/Published online: 4 September 2015

(C) The Author(s) 2015. This article is published with open access at Springerlink.com

\begin{abstract}
Insect herbivores can increase the suitability of host plants for conspecifics by inducing susceptibility. Induced susceptibility can be separated into feeding facilitation, whereby herbivore feeding increases performance of conspecifics regardless of the genotype of the herbivore or plant, and obviation of resistance, whereby feeding by a virulent herbivore increases performance of avirulent conspecifics on resistant plants. Both forms occur between Aphis glycines (Hemiptera: Aphididae) and soybean. In natural and agricultural settings, A. glycines populations can colonize plants for brief periods before emigrating or being removed due to predation or insecticides. It is unclear if induced susceptibility lasts beyond the period when A. glycines are present on the plant. We measured the duration of induced susceptibility in the A. glycines-soybean system within a growth chamber by removing inducer populations after $24 \mathrm{~h}$. We used an A. glycines-resistant soybean infested with an inducer population of either virulent, avirulent, or no aphids. Response populations of either virulent or avirulent aphids were added at three postinfestation times $(24,120,216 \mathrm{~h})$ and their densities measured 11 days after infestation. Feeding facilitation was lost within $24 \mathrm{~h}$ of the removal of avirulent inducer populations, and obviation of resistance diminished over time and was completely lost within $216 \mathrm{~h}$ of the removal
\end{abstract}

Handling Editor: Joe Louis.

Adam J. Varenhorst

ajv@iastate.edu

Matthew E. O'Neal

oneal@iastate.edu

1 Department of Entomology, Iowa State University, 117 Insectary, Ames, IA 50011, USA of the virulent inducer populations. We discuss how these results support a hypothesis that virulence in A. glycines is due to effector proteins secreted by feeding aphids. We suggest that the duration of induced susceptibility may impact the durability of A. glycines resistance in soybean.

Keywords Soybean aphid - Induced susceptibility . Feeding facilitation - Obviation of resistance

\section{Introduction}

Insect herbivores can directly or indirectly alter the suitability of a host plant for both conspecifics and heterospecifics (Karban and Myers 1989). Such alterations of host plants can be categorized as either negative (e.g., induced resistance) or positive (e.g., induced susceptibility) for subsequent herbivores (Karban and Myers 1989; Price et al. 2011). These herbivore-induced effects in plants may affect initial herbivore survival, fecundity, and/or preference for the host plant, and they may also affect subsequent conspecific or heterospecific herbivore populations (Karban and Baldwin 1997; Price et al. 2011). The duration of either induced resistance or susceptibility vary, classified as either short- or long-term effects, depending upon the plant-insect system studied (Karban and Myers 1989; Karban and Baldwin 1997). In general, short-term responses are elicited by and affect the initial herbivore, while long-term responses are elicited by an initial herbivore (i.e., an inducer population) and affect the survival of herbivores that arrive after the initial herbivore (i.e., a response population) (Karban and Myers 1989; Karban and Baldwin 1997). Some potential causes of induced effects include physical contact, chemical cues, plant viruses, insect endosymbionts, or insect proteins (Schoonhoven 
et al. 2005; Oliver et al. 2010; Casteel and Jander 2013; Pitino and Hogenhout 2013).

There are several examples of induced susceptibility benefiting aphids (Hemiptera: Aphididae) on a shared host plant. Initial Acyrthosiphum pisum Harris (Hemiptera: Aphididae) feeding led to improved suitability of Vicia faba (Fabales: Fabaceae) for subsequent A. pisum populations (Takemoto et al. 2013). Similar results have been observed regarding Myzus periscae (Hemiptera: Aphididae) on Prunus persica (Rosales: Rosaceae) (Sauge et al. 2006). At least six other aphid species are recognized as inducing susceptibility in their host plants (Karban and Baldwin 1997). Of these, all are reported as affecting the same generation of aphids, but there are also two for which the induced susceptibility also altered the plant for the next generation of aphids on perennial plants (Fisher 1987; Messina et al. 1993). It is unknown whether induced susceptibility is a general phenomenon observed across all aphid-plant systems or is the result of specialization. Adding to the growing list of cases, in which induced susceptibility occurs, especially for aphids that are economic pests of crops, may lead to better pest management. Shedding light on this phenomenon may also improve our understanding of aphid resistance in crop plants, and the nature of virulence in biotypes that can survive on resistant crop varieties.

For example, Aphis glycines is an invasive pest of soybean in North America that can greatly reduce yield (Ragsdale et al. 2011). Soon after the discovery of $A$. glycines in the USA, soybean breeders discovered several genes that confer resistance to A. glycines (i.e., Rag genes) in the soybean germplasm (reviewed in Ragsdale et al. 2011). In a laboratory setting, the response of resistant and susceptible soybean to A. glycines infestation differed, with resistant plants responding more rapidly to infestations than susceptible plants (Studham and MacIntosh 2013). When tested in the field, Rag-containing plants consistently have fewer A. glycines than aphid-susceptible cultivars, but resistant cultivars are rarely free of aphids and sometimes support large populations (Hesler et al. 2013) that exceed an economic threshold (McCarville et al. 2014). Despite the genetic bottleneck associated with A. glycines arrival in North America (Michel et al. 2011) and the limited commercial use of Rag genes in North America (Hesler et al. 2013), several virulent biotypes have been found in the USA (Kim et al. 2008; Hill et al. 2010; Alt and RyanMahmutagic 2013). These virulent biotypes are defined by the specific Rag genes on which they can survive. To date, for every Rag gene that has been incorporated into a soybean cultivar either alone or in a combination, a virulent biotype has been found in the USA (Kim et al. 2008; Hill et al. 2010; Alt and Ryan-Mahmutagic 2013).
Feeding by A. glycines induces susceptibility for subsequent $A$. glycines on both susceptible and resistant soybean varieties (Varenhorst et al. 2015). This induced susceptibility was observed with both avirulent and virulent biotypes and could be divided into two different mechanisms: feeding facilitation (Denno and Benrey 1997) and obviation of resistance (Baluch et al. 2012). For $A$. glycines and soybean, both mechanisms were observed (Varenhorst et al. 2015). For example, feeding facilitation was observed when A. glycines populations on aphid-resistant soybean had larger populations after initial herbivory by an inducer population of A. glycines when compared to a control lacking an inducer population, regardless of its biotype that resulted in a $714 \%$ increase in population density. Obviation of resistance occurs when a virulent biotype overcomes a plant's resistance such that avirulent biotypes survive as if the plant is susceptible. Obviation of resistance was confirmed by significant increases in avirulent $A$. glycines populations on resistant soybean after initial herbivory by an inducer population of virulent A. glycines when compared to controls lacking a virulent inducer population. There was a $2078 \%$ increase in population density between the avirulent response population with no inducer treatment and the avirulent response population with a virulent inducer treatment. Obviation of Rag resistance by virulent A. glycines resulted in response populations of avirulent populations that were equivalent to that of a virulent response population with a virulent inducer (Varenhorst et al. 2015). The consequences of both of these mechanisms are relevant in light of recent findings by Wenger et al. (2014), which suggest an improvement in fitness for avirulent A. glycines on aphid-resistant soybean decreases the relative frequency of virulent biotypes. These results align with the goal of an insect resistance management (IRM) plan to reduce/slow the spread of virulence. The extent that induced susceptibility can support a IRM plan is unknown, though initial modeling suggests that this phenomenon will reduce the frequency of virulent biotypes when a refuge of aphidsusceptible soybean is planted with the aphid-resistant cultivar (Varenhorst et al. 2015).

In the previous experiments (Varenhorst et al. 2015) with A. glycines, plants were co-infested with both an inducer population and a subsequent response population. In natural and agricultural settings, aphids form colonies on plants for brief periods before leaving due to emigration, predation, or an insecticide application. Subsequent recolonization can occur, often with populations that exceed the densities of the previous colony. This is typically referred to as pest resurgence, and in the case where insecticides are used, a function of the removal of aphid predators (Pedigo and Rice 2009). It is not known if the 
impact of an inducer population on a soybean plant will persist if it is removed from the plant, potentially contributing to a pest's resurgence. Our objective was to determine whether induced susceptibility persists in the absence of an inducer population on soybean. The duration of induced susceptibility was tested using the methods developed by Varenhorst et al. (2015). Furthermore, we explored if the two components of induce susceptibility (feeding facilitation and obviation of resistance) differed in their persistence after the inducer population was removed. The design was amended with both a virulent and avirulent biotype of A. glycines and a Rag-containing soybean variety to explore the persistence and duration of both feeding facilitation and obviation of resistance.

\section{Materials and methods}

\section{Aphid colonies and soybean cultivars}

Two populations of A. glycines from The Ohio State University were used for this experiment. The populations are defined by their response to Ragl, an avirulent population (biotype-1) and a virulent population (biotype-2) (Kim et al. 2008). Individuals used to create these populations were initially collected and identified in Illinois (Kim et al. 2008). The avirulent population was raised on aphid-susceptible soybean (IA3027), while the virulent population was raised on a near-isogenic, aphid-resistant soybean containing the Ragl gene (IA3027RA1). These two cultivars are near isogenic, sharing approximately $93.75 \%$ genetic identity (Wiarda et al. 2012).

\section{Duration of induced susceptibility effects}

We hypothesized that both feeding facilitation and obviation of resistance would persist in soybean after the removal of the initial A. glycines populations. We measured the duration of these effects by infesting Ragl containing soybean (IA3027RA1) with an initial population of A. glycines, termed an inducer population, and allow them to feed for a period of $24 \mathrm{~h}$. After $24 \mathrm{~h}$, the inducer population was removed using a fine tip paintbrush, and a subsequent population of A. glycines, termed response populations, was infested. The response populations were defined by the time between the removal of the inducer population and their infestation (post-infestation interval, or PII). The response population densities were measured 11 days after being added to plants, a time span that allows for the production of two generations of A. glycines (McCornack et al. 2004). Table 1 outlines the timing of these events. During the 11-day period, alates of A. glycines were not observed.
Table 1 Sequence of events for legacy effect experiment

\begin{tabular}{|c|c|c|c|}
\hline Event & $24 \mathrm{~h}$ & $120 \mathrm{~h}$ & $216 \mathrm{~h}$ \\
\hline Planting & Day 1 & Day 1 & Day 1 \\
\hline Infestation of inducer ${ }^{\mathrm{a}}$ & Day 17 & Day 17 & Day 17 \\
\hline Removal of inducer & Day 18 & Day 18 & Day 18 \\
\hline Infestation of response $\mathrm{e}^{\mathrm{b}}$ & Day 18 & Day 22 & Day 26 \\
\hline Counting of response & Day 29 & Day 33 & Day 37 \\
\hline
\end{tabular}

${ }^{a}$ Inducer populations consisted of 50 avirulent, 50 virulent, or no $A$. glycines

${ }^{\mathrm{b}}$ Response populations consisted of 5 avirulent A. glycines

To test our hypothesis, we used nine treatments. Each treatment was a combination of two factors, inducer populations and response population infestation time. The three inducer populations used were: no inducer (none), 50 avirulent $A$. glycines (avirulent), and 50 virulent $A$. glycines (virulent). Three response infestation times used: 24, 120, and $216 \mathrm{~h}$ PII. Inducer populations of either no aphids, biotype-1, or biotype-2 A. glycines nymphs were applied to the first full trifoliate of individual potted plants when the plants reached the second trifoliate growth stage. Each individual potted plant was enclosed within a mesh net to prevent plant-to-plant movement of either the inducer or the subsequent response population. After $24 \mathrm{~h}$ the inducer populations were removed from all of the previously infested plants using a fine tip paintbrush. Inducer populations remained on the first full trifoliate for the 24-h period, although they were not caged onto the trifoliate. Varenhorst et al. (2015) determined that the maximum effect of induced susceptibility occurred with an inducer population of $50 \mathrm{~A}$. glycines. Therefore, to determine the duration of induced susceptibility, inducer populations of 50 avirulent and 50 virulent $A$. glycines were used. Both inducer population and response population were compromised of mixed aged A. glycines nymphs.

Infestations of the response population were applied at three intervals, defined by the time between the removal of the inducer population and the infestation of the response population. These treatments occurred at 24, 120, and $216 \mathrm{~h}$ PII. Response populations were added to the second full trifoliate of each plant and consisted of five avirulent $A$. glycines that were allowed to move freely about the plant. The total number of A. glycines present in each response population was counted 11 days after the response population was infested. We measured both the presence and length of induced susceptibility by adding response populations at various times after the removal of the inducer population (Table 1).

Each experimental unit (i.e., potted plant) was grown in 16-cm diameter pots in a Percival E41L2C9 growth 
chamber (Percival Scientific, Incorporated, Perry, IA) using a 14:10 light/dark cycle and a constant temperature of $27{ }^{\circ} \mathrm{C}$ with a relative humidity of $60 \%$. Each of the experimental units received one of the nine treatment combinations. This experiment was repeated twice in a growth chamber using a randomized complete block design with three blocks per repetition (six total experimental units per treatment).

\section{Statistical Analysis}

To address our a priori hypotheses, we analyzed the number of A. glycines per plant in the response population at 11 days after plants were infested with response populations. Data were analyzed separately for each PII time point. To reduce heteroscedasticity, the A. glycines per plant data were log transformed. All data were analyzed using the PROC MIXED procedure with SAS statistical software version 9.3 (SAS Institute, Cary, NC). The impact of each treatment factor was determined using an analysis of variance (ANOVA). The statistical model used to analyze data for each of the PII included the fixed effect of inducer population treatment. The random effects included repetition, inducer population treatment $\times$ repetition, and block(repetition). We tested for the significance of all random effects using a log-likelihood ratio statistic (-2RES Log Likelihood). The log-likelihood statistic follows an approximate $\chi^{2}$ distribution with one degree of freedom, and was used to determine whether inclusion of each random effect significantly improved model fit over the null model (Littell et al. 2002).

The duration of the induced susceptibility effects was determined by comparing the effect of the inducer population treatment factor on the response population abundance at each PII. If we determined that induced susceptibility was present, we next tested whether it was due to the effect of feeding facilitation, or obviation of resistance. We tested for these effects using contrast statements within PROC MIXED using the same model as previously described with a significance level of $P<0.05$. At each PII time point, the inducer population treatments were simultaneously compared. Feeding facilitation was confirmed if the response population on the avirulent inducer treatment was significantly greater than the response population of the no inducer control (Denno and Benrey 1997; Varenhorst et al. 2015). Obviation of resistance was confirmed if the response population of the virulent inducer treatment was significantly greater than the response population of the avirulent inducer treatment (Baluch et al. 2012; Varenhorst et al. 2015).

\section{Results}

\section{Duration of induced susceptibility}

We observed significant differences in the abundance of a response population with variation in the inducer population at the 24 and $120 \mathrm{~h}$, but not the $216 \mathrm{~h}$ PII (Table 2). This was observed by analyzing data for the significance of a fixed effect of inducer population treatment for each of the PII levels. In the $24 \mathrm{~h}$ PII experiment, we observed a significant interaction between repetition and inducer treatment. This interaction was apparent when we compared the averages from the two repetitions from the $24 \mathrm{~h}$ PII experiment for the treatments receiving an inducer population compared to the no inducer treatment. There was little variation between the two repetitions for the no inducer treatment (an average difference of 2 aphids per plant). For the avirulent and virulent inducer treatments, we observed an average difference of 17 and 75 aphids per plant, respectively, between the two repetitions. Despite this interaction, we consistently observed more aphids on plants that received avirulent aphids as an inducer population than no inducer in both repetitions, and plants that were assigned virulent aphids as an inducer consistently had more aphids than either of the other two treatments.

Because the inducer population significantly affected the response populations at the 24 and $120 \mathrm{~h}$ PII, we compared the impact of the various inducer population treatments at each PII. The response population on plants receiving an avirulent inducer population (i.e., avirulent treatment) was significantly greater than on plants that did not have an inducer population (i.e., none treatment) at $24 \mathrm{~h}$ PII $(F=128.63 ; d f=1,2 ; P<0.0077)$ (Fig. $1 ; 24 \mathrm{~h} \mathrm{PII})$, but not at $120 \mathrm{~h}$ PII or $216 \mathrm{~h}$ PII. The response population for the virulent treatment was significantly greater than that of the response population for the avirulent treatment at $24 \mathrm{~h}$ PII $(F=843.04 ; d f=1,2 ; P<0.0012)$ (Fig. $1 ; 24$ h PII) and $120 \mathrm{~h}$ PII $(F=42.92 ; d f=1,2 ; P<0.0225)$ (Fig. 1 ; $120 \mathrm{~h}$ PII). At $216 \mathrm{~h}$ PII there was no significant differences among the treatments. Therefore, induced susceptibility effects were observed for the avirulent treatment at $24 \mathrm{~h}$ PII, and for the virulent treatment at $24 \mathrm{~h}$ PII and 120 h PII.

\section{Discussion}

Our results demonstrate that A. glycines feeding alters resistant soybean such that it is more susceptible to future infestations of conspecifics. The length of time this effect 
Table 2 Analysis of variance tables of treatment effects

\begin{tabular}{lllc}
\hline Effect & Fixed/Random & $d f$ & $F$ statistic $^{\mathrm{a}} / \chi^{2}$ \\
\hline 24 h PII $^{\mathrm{b}}$ & $\mathrm{R}$ & 1 & \\
Repetition & $\mathrm{R}$ & 1 & 0.20 \\
Block (repetition) & $\mathrm{F}$ & 2,2 & 1.00 \\
Inducer population & $\mathrm{R}$ & 1 & $867.31^{* *}$ \\
Repetition $\times$ inducer population & & & $4.30^{*}$ \\
120 h PII & $\mathrm{R}$ & 1 & \\
Repetition & $\mathrm{R}$ & 1 & 0.40 \\
Block (repetition) & $\mathrm{F}$ & 2,2 & $5.10^{*}$ \\
Inducer population & $\mathrm{R}$ & 1 & $50.65^{*}$ \\
Repetition $\times$ inducer population & & & 1.20 \\
216 h PII & $\mathrm{R}$ & 1 & \\
Repetition & $\mathrm{R}$ & 1 & 0.20 \\
Block (repetition) & $\mathrm{F}$ & 2,2 & 0.00 \\
Inducer population & $\mathrm{R}$ & 1 & 4.83 \\
Repetition $\times$ inducer population & & 1 & 0.50 \\
\hline
\end{tabular}

${ }^{a}$ An F statistic was used to test for the significance of fixed effects, while a $\chi^{2}$ test was used for random effects

b Post-inducer population infestation

* Significant effect at $P<0.05, * * P<0.01, * * * P<0.0001$

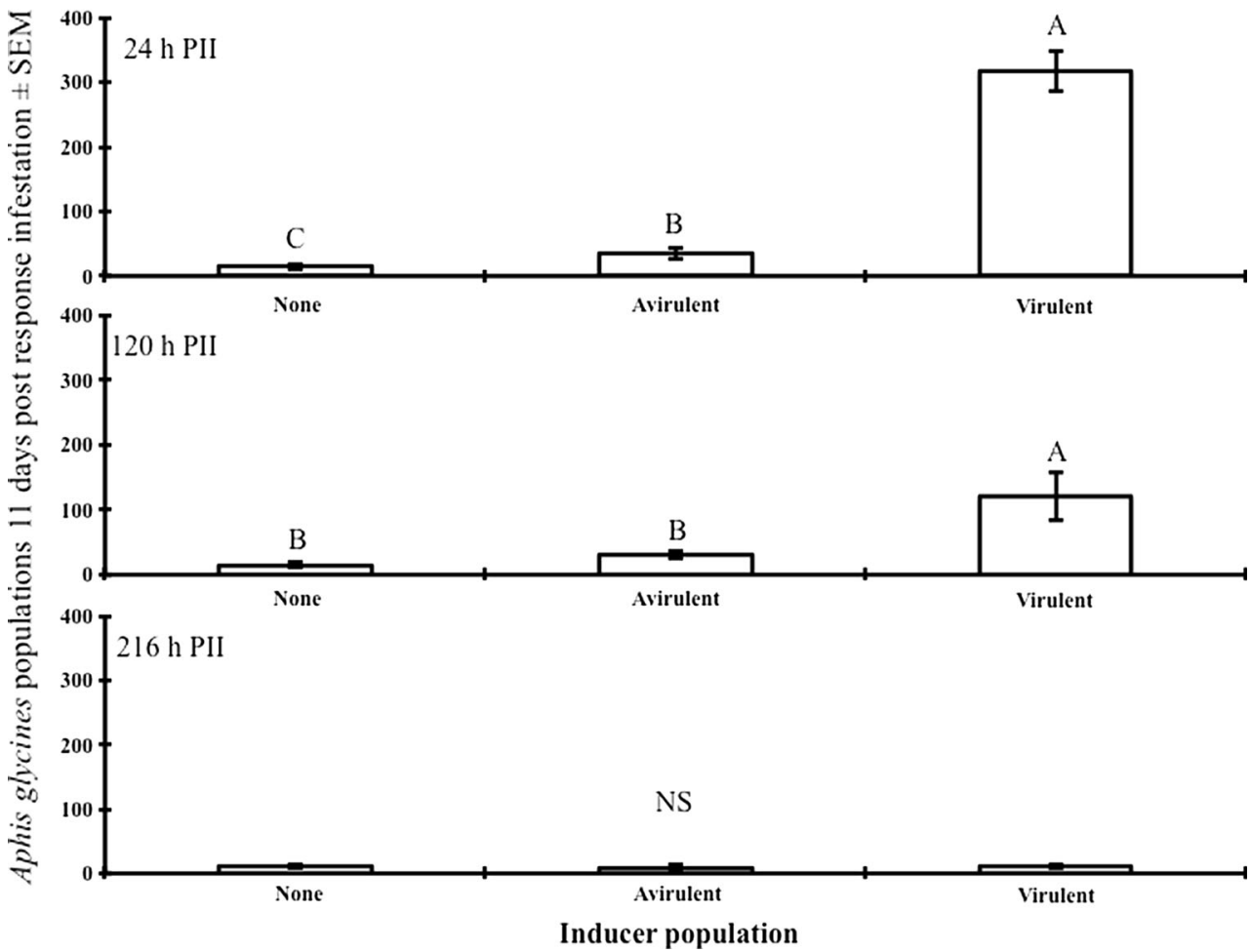

Fig. 1 The duration of induced susceptibility effects was measured in a growth chamber experiment. Aphid-resistant plants were infested with an inducer population of either virulent, avirulent, or no aphids for $24 \mathrm{~h}$ and then removed from plants. Response populations were then added at three postinducer infestation times $(24 \mathrm{~h}$ PII, $120 \mathrm{~h}$ PII, and $216 \mathrm{~h}$ PII). Capital letters indicate significance among treatments $(P<0.05)$ lasts after the inducer population of A. glycines is removed varies by aphid biotype (i.e., virulence). Increases in $A$. glycines populations due to an inducer population (i.e., induced susceptibility) occurred in two ways, by feeding facilitation (Denno and Benrey 1997; Price et al. 2011) or obviation or resistance (Baluch et al. 2012). Feeding facilitation was observed when the response population increased after the plant experienced herbivory from an avirulent inducer treatment compared to the control where no inducer was present. Feeding facilitation was only 
observed at $24 \mathrm{~h}$ PII. Obviation of resistance was observed when the response population increased on the virulent inducer treatment compared to the avirulent inducer treatment, which occurred at 24 and at $120 \mathrm{~h}$ PII but with diminished impact. There was no evidence of either feeding facilitation or obviation of resistance at $216 \mathrm{~h}$ PII for any of the treatments. Therefore, we conclude that in the absence of the inducer population the effect of feeding facilitation persists for $24 \mathrm{~h}$ and the effect of obviation resistance persists for at least $120 \mathrm{~h}$. Based on these results, the observed feeding facilitation effect is best described as a short-term induced effect. The obviation of Rag resistance persisted for at least $120 \mathrm{~h}$ and would possibly affect subsequent $A$. glycines and therefore is best described as a long-term induced effect (Karban and Baldwin 1997; Price et al. 2011).

Our experiment was not designed to compare the impact of induced susceptibility at different time points. For example we cannot compare the treatment across PII levels. However, we observed an interesting change in the difference between treatments receiving no inducer versus an avirulent inducer between the 24 and 120 PII levels: this difference was significant at the $24 \mathrm{~h}$ PII but not 120 PII. This difference suggests that feeding facilitation did not occur at $120 \mathrm{~h}$ PII level. But between the two PII levels, there was only a difference of 4 aphids per plant between the avirulent treatments at 24 and 120 PII. It may be that we were unable to observe feeding facilitation at the $120 \mathrm{~h}$ PII level because of insufficient statistical power. Regardless of whether feeding facilitation still occurs $120 \mathrm{~h}$ after an inducer population was removed, we note that our experimental design was sufficient to observe a difference between the virulent and avirulent inducer treatments. We suggest that this reflects a greater impact of obviation of resistance on the plants' physiology compared to feeding facilitation.

Based on the duration of the obviation of resistance, we hypothesize a mechanism responsible for this effect. There are several factors that can explain how the physiology of a plant can be altered by aphids, including endosymbionts (Oliver et al. 2010), viruses (Mauck et al. 2012; Casteel and Jander 2013), and effector proteins found in salivary excretions (Rodriguez and Bos 2013). These factors may help explain how an avirulent aphid could survive on a resistant plant that is co-infested with a virulent biotype. For example, virulence could be due to the presence of specialized endosymbionts (Oliver et al. 2010). However, we did not observe evidence of the horizontal transmission of endosymbionts between the virulent and avirulent populations (i.e., virulence was not observed at each PII time point). In addition, endosymbiotic bacteria are unlikely to be the cause of obviation of resistance as horizontal transmission of bacteria is rare. Also our inducer and response populations were temporally and spatially separated on the soybean plant making horizontal transmission even less probable (Oliver et al. 2010).

In a review, Mauck et al. (2012) describe the potential for plant viruses to affect aphid settling and feeding preferences resulting in greater attraction to a host plant. In contrast to non-persistently transmitted viruses, persistently transmitted plant viruses have the potential to make the host plant more suitable and promote long-term feeding. Persistently transmitted viruses generally are acquired through extended feeding bouts and benefit from vector settling. Plant virus infection is unlikely to be the cause of the observed obviation of resistance as the only persistently transmitted soybean virus in North America is Soybean dwarf virus (Hartman 1999), which is rarely vectored by $A$. glycines (Harrison et al. 2005; Wang et al. 2006; Damsteegt et al. 2011). Additional evidence that a plant virus is unlikely responsible for the obviation of resistance is the reduction in the response populations at 120 and $216 \mathrm{~h}$ for the virulent inducer population treatment. This observation is not consistent with results from other studies of plant virus infection on aphid populations in which the virus infection improved aphid populations for up to one week post-infection (Casteel et al. 2014). Due to the asymptomatic nature of our plants and the reduction of the effect over time, we conclude that a plant virus was not the cause of the obviation of resistance.

We suggest that effector proteins are the most probable explanation of obviation of resistance. Previous research has indicated that aphid effector proteins are capable of suppressing host plant defense pathways and modulating a range of host cell processes (Hogenhout and Bos 2011; Pitino and Hogenhout 2013; Rodriguez and Bos 2013). Pitino and Hogenhout (2013) demonstrated that the impact of aphid effector proteins vary by aphid species. On Arabidopsis (Brassicaceae), homologs of effector proteins from A. pisum, a specialist of plants in the Fabaceae family, did not improve reproduction of $M$. periscae, a generalist capable of utilizing plants from multiple families. In contrast, expression of $M$. periscae effector homologs did result in increased $M$. periscae reproduction. Both enzymes and binding proteins are present in the saliva of aphids and are potential explanations for how aphids influence the host plant's defense response to herbivory (Will et al. 2007; Harmel et al. 2008; Hogenhout and Bos 2011). Aphid effector proteins may possibly explain the differences in aphid specialization (i.e., diet breadth) and also biotypic variation within an aphid species in the form of virulence to aphid-resistant traits (Rodriguez and Bos 2013). Our hypothesis is further supported by Bansal et al. (2014)'s discovery of 47 protein transcripts present in A. glycines that matched effectors present in A. pisum with known functions. Finally, the ultimate source of the effector 
proteins may not be limited to the aphid. Proteins produced from endosymbiotic bacteria can also be transmitted to the host plant and affect the survival of the aphid host (Chaudhary et al. 2014). However, to date this phenomenon has been limited to an endosymbiont-produced protein (GroEL) that induces resistance in the host plant to aphids. We are unaware of endosymbionts that produce proteins that alter plant physiology such that it is a better host for the aphid. Regardless of the source, the A. glycines-soybean system suggests that the impact of these proteins is systemic and alters the plant for at least $120 \mathrm{~h}$.

The short duration and apparent degradation of the effect between $24 \mathrm{~h}$ PII and $120 \mathrm{~h}$ PII for obviation of resistance further support the role of effector proteins in this aphid-plant system. The decline of obviation of resistance that was observed over time in our experiment may be attributed to an aphid-produced enzyme or protein present in the host plant and its subsequent degradation by the plant (Boyes et al. 1998; Martin et al. 2003). Therefore, we hypothesize that the effect of obviation of resistance is strongest when the inducer and response populations are present on the plant simultaneously, but the effect persists until the putative effector proteins are degraded. This is likely a function of the density of the aphids that are injecting effector proteins and the capacity of the plant to recognize and/or degrade them.

Previous studies in which the transcriptional response of either A. glycines or soybean to each other have focused on either the immediate response within a $24-\mathrm{h}$ period or delayed responses of several days. Studham and Macintosh (2013) measured the response of susceptible and resistant soybean to A. glycines feeding after plants were infested for 1 or 7 days. Bansal et al. (2014) measured the response of biotype-1 A. glycines feeding on Ragl soybean after $12 \mathrm{~h}$. Given our results, these studies with avirulent $A$. glycines most likely observed the effect of both feeding facilitation (e.g., avirulent aphids feeding on resistant soybean) and obviation of resistance (e.g., virulent aphids feeding on susceptible soybean). If future studies are focused on the mechanism of how virulent aphids overcome Rag resistance, then the amount of time in which the plant is allowed to respond to A. glycines feeding should be adjusted to account for only obviation of resistance. Our data suggest that this impact may be most noticeable at $120 \mathrm{~h}$ post-infestation.

The results from this paper provide a framework for future research on the mechanism of A. glycines virulence. Future work should investigate effector protein candidates and determine the mechanism of these effector proteins as potential targets for novel pest control technologies. We predict that if effector proteins are the cause of the biotypic variation in virulence toward Rag genes, then variation within the effector proteins among these biotypes should also be present. This variation may not only be responsible for the virulence of a biotype toward a resistance gene, but may also affect the duration of the obviation of resistance effect (i.e., the legacy of effector proteins may differ by biotype). Finally, the study of induced susceptibility within the A. glycines-soybean system has been limited to microcosms within a laboratory setting. The study of this phenomenon in a field setting will have to account for the impact of natural enemies on A. glycines, which suffers significant mortality from predators commonly found in North America (Ragsdale et al. 2011).

Acknowledgments This study was funded in part by the Soybean Checkoff through a grant from the North Central Soybean Research Program. We thank Dr. Andy Michel for the initial A. glycines populations and also for comments on earlier versions of this manuscript.

Open Access This article is distributed under the terms of the Creative Commons Attribution 4.0 International License (http://crea tivecommons.org/licenses/by/4.0/), which permits unrestricted use, distribution, and reproduction in any medium, provided you give appropriate credit to the original author(s) and the source, provide a link to the Creative Commons license, and indicate if changes were made.

\section{References}

Alt J, Ryan-Mahmutagic M (2013) Soybean aphid biotype 4 identified. Crop Sci 53:1491-1495

Baluch SD, Ohm HW, Shukle JT, Williams CE (2012) Obviation of wheat resistance to the Hessian fly through systemic induced susceptibility. J Econ Entomol 105:642-650

Bansal R, Mian MAR, Mittapalli O, Michel AP (2014) RNA-Seq reveals a xenobiotic stress response in the soybean aphid, Aphis glycines, when fed aphid-resistant soybean. BMC Genom 15:972-985

Boyes DC, Nam J, Dangl JL (1998) The Arabidopsis thaliana RPMI disease resistance gene product is a peripheral plasma membrane protein that is degraded coincident with the hypersensitive response. Proc Natl Acad Sci 95:15849-15854

Casteel CL, Jander G (2013) New Synthesis: investigating mutualisms in virus-vector interactions. J Chem Ecol 39:809

Casteel CL, Yang CA, Nanduri C, De Jong HN, Whitham SA, Jander G (2014) The Nla-Pro protein of Turnip mosaic virus improves growth and reproduction of the aphid vector, Myzus periscae (green peach aphid). Plant J 77:653-663

Chaudhary R, Atamian HS, Shen Z, Briggs SP, Kaloshian I (2014) GroEL from the endosymbionts Buchnera aphidicola betrays the aphid by triggering plant defense. Proc Natl Acad Sci USA 111:8919-8924

Cuddington K (2011) Legacy effects: the persistent impact of ecological interactions. Biol Theory 6:203-210

Damsteegt VD, Stone AL, Kuhlmann M, Gildow FE, Domier LL, Sherman DJ, Tian B, Schneider WL (2011) Acquisition and transmissibility of U.S. Soybean dwarf virus isolates by the soybean aphid Aphis glycines. Plant Dis 95:945-950

Denno RF, Benrey B (1997) Aggregation facilitates larval growth in neotropical nymphalid butterfly Chlosyne janais. Ecol Entomol 22:133-141

Fisher M (1987) The effect of previously infested spruce needles on the growth of the green spruce aphid, Elatobium abietinum, and the effect of the aphid on the amino acid balance of the host plant. Ann Appl Biol 111:33-41 
Harmel N, Letocart E, Cherqui A, Giordanengo P, Mazzuccheli G, Guillonneau F, De Pauw E, Haubruge E, Francis F (2008) Identification of aphid salivary proteins: a proteomic investigation of Myzus periscae. Insect Mol Biol 17:165-174

Harrison B, Steinlage TA, Domier LL, D'Arcy CJ (2005) Incidence of Soybean dwarf virus and identification of potential vectors in Illinois. Plant Dis 89:28-32

Hartman GL (1999) Compendium of soybean diseases, 4th edn. American Phytopathological Society, St. Paul

Hesler LS, Chiozza MV, O'Neal ME, MacIntosh GC, Tilmon KJ, Chandrasena DI, Tinsley NA, Cianzio SR, Costamagna AC, Cullen EM, DiFonzo CD, Potter BD, Ragsdale DW, Steffey K, Koehler KJ (2013) Performance and prospects of Rag genes for management of soybean aphid. Entomol Exp Appl 147:201-216

Hill CB, Crull L, Herman TK, Voegtlin DJ, Hartman GL (2010) A new soybean aphid (Hemiptera: Aphididae) biotype identified. J Econ Entomol 103:509-515

Hogenhout SA, Bos JIB (2011) Effector proteins that modulate plantinsect interactions. Curr Opin Plant Biol 14:422-428

Karban R, Baldwin IT (1997) Induced responses to herbivory. The University of Chicago Press, Chicago, pp 104-166

Karban R, Myers JH (1989) Induced plant responses to herbivory. Annu Rev Ecol Syst 20:331-348

Kim K, Hill CB, Hartman GL, Mian MAR, Diers BW (2008) Discovery of soybean aphid biotypes. Crop Sci 48:923-928

Littell RC, Stroup WW, Freund RJ (2002) SAS for linear models, 4th edn. SAS Institute, Cary

Martin GB, Bogdanove AJ, Sessa G (2003) Understanding the functions of plant disease resistance proteins. Ann Rev Plant Biol 54:23-61

Mauck K, Bosque-Pérez NA, Eigenbrode SD, De Moraes CM, Mescher MC (2012) Transmission mechanisms shape pathogen effects on host-vector interactions: evidence from plant viruses. Funct Ecol 26:1162-1175

McCarville MT, O'Neal ME, Potter BD, Tilmon KJ, Cullen EM, McCornack BP, Tooker JF, Prischmann-Voldseth DA (2014) One gene versus two: a regional study on the efficacy of single gene versus pyramided resistance for soybean aphid management. J Econ Entomol 107:1680-1687

McCornack BP, Ragsdale DW, Venette RC (2004) Demography of soybean aphid (Homoptera: Aphididae) at summer temperatures. J Econ Entomol 97:854-861

Messina FJ, Jones TA, Nielson DC (1993) Performance of the Russian wheat aphid (Homoptera: Aphididae) on perennial range grasses: effects of previous defoliation. Environ Entomol 22:1349-1354

Michel AP, Mian MAR, Davila-Olivas NH, Canas LA (2010) Detached leaf and whole plant assays for soybean aphid resistance: differential responses among resistance sources and biotypes. J Econ Entomol 103:949-957

Michel AP, Omprakah M, Mian MAR (2011) Evolution of soybean aphid biotypes: understanding and managing virulence to host- plant resistance. In: Sudarec A (ed) Soybean-molecular aspects of breeding. InTech, New York, pp 355-372

Oliver KM, Degnan PH, Burke GR, Moran NA (2010) Facultative symbionts in aphids and the horizontal transfer of ecologically important traits. Annu Rev Entomol 55:247-266

Pedigo LP, Rice ME (2009) Entomology and pest management, 6th edn. Pearson Education, New Jersey, pp 594-595

Pitino M, Hogenhout SA (2013) Aphid protein effectors promote aphid colonization in a plant species-specific manner. Mol Plant Microbe Interact 1:130-139

Price PW, Denno RF, Eubanks MD, Finke DL, Kaplan I (2011) Insect ecology: behavior, populations, and communities. Cambridge University Press, New York, pp 184-223

Ragsdale DW, Landis DA, Brodeur J, Heimpel GE, Desneux N (2011) Ecology and management of the soybean aphid in North America. Annu Rev Entomol 56:375-399

Rodriguez PA, Bos JIB (2013) Toward understanding the role of aphid effectors in plant infestation. Mol Plant Microbe Interact $1: 25-30$

Sauge MH, Mus F, Lacroze JP, Pascal T, Kervella J, Poessel JL (2006) Genotypic variation in induced resistance and induced susceptibility in the peach-Myzus periscae aphid system. Oikos 113:305-313

Schoonhoven LM, van Loon JJA, Dicke M (2005) Insect-plant biology, 2nd edn. Oxford University Press Inc, New York

Studham ME, MacIntosh GC (2013) Multiple phytochrome signals control the transcriptional response to soybean aphid infestation in susceptible and resistant soybean plants. Mol Plant Microbe Interact 26:116-129

Takemoto H, Uefune M, Ozawa R, Arimura GI, Takabayashi J (2013) Previous infestation of pea aphids Acyrthosiphon pisum on broad bean plants resulted in the increased performance of conspecific nymphs on the plants. J Plant Interact 8:370-374

Varenhorst AJ, McCarville MT, O'Neal ME (2015) An induced susceptibility response in soybean promotes avirulent soybean aphid populations on resistant soybean. Eviron Entomol 44:658-667

Wang RY, Kritzman A, Hershman DE, Ghabrial SA (2006) Aphis glycines as a vector of persistently and nonpersistently transmitted viruses and potential risks for soybean and other crops. Plant Dis 90:920-926

Wenger J, Ramstad M, Mian MAR, Michel A (2014) The use of refuge in host plant resistance systems for the control of virulent biotype adaptation in the soybean aphid (Hemiptera: Aphididae). J Econ Entomol 107:1599-1609

Wiarda SL, Fehr WR, O’Neal ME (2012) Soybean aphid (Hemiptera: Aphididae) development on soybean with Rag1 alone, Rag2 alone, and both genes combined. J Econ Entomol 105:252-258

Will T, Tjallingii WF, Thonnessen A, van Bel AJE (2007) Molecular sabotage of plant defense by aphid saliva. Proc Natl Acad Sci USA 104:10536-10541 